Proceedings

\title{
Current Vegetation of Danube Islands Refers to Historical Land Uses and Recent Human Interventions ${ }^{\dagger}$
}

\author{
Szilvia Ádám 1,* and Ákos Malatinszky ${ }^{2}$
}

Citation: Ádám, S.; Malatinszky, Á. Current Vegetation of Danube Islands Refers to Historical Land Uses and Recent Human Interventions.

Proceedings 2021, 68, x.

https://doi.org/10.3390/xxxxx

Published: date

Publisher's Note: MDPI stays neutral with regard to jurisdictional claims in published maps and institutional affiliations.

Copyright: (C) 2021 by the authors. Submitted for possible open access publication under the terms and conditions of the Creative Commons Attribution (CC BY) license (http://creativecommons.org/licenses /by/4.0/).
1 Department of Nature Conservation and Landscape Management, Hungarian University of Agriculture and Life Sciences, Páter K 1, 2100 Gödöllő, Hungary

2 Department of Nature Conservation and Landscape Management, Hungarian University of Agriculture and Life Sciences, Páter K 1, 2100 Gödöllő, Hungary; malatinszky.akos@uni-mate.hu

* Correspondence: sargabogar@gmail.com; Tel.: +36-30-305-4558

+ Presented at the 1st International Electronic Conference on Biological Diversity, Ecology and Evolution, 1531 March 2021; Available online: https://bdee2021.sciforum.net/.

\begin{abstract}
The consequences of various old-time and recent human interventions on the Danube river are enormous, and still new developments are planned. Therefore, we targeted to explore the current vegetation of the islands on the Hungarian Danube stretch between Vének and Budapest (149 rkm long), and the reasons for its various appearance. The first pioneer habitats on riparian zones of islands and gravel bars where the surface raises above water-level are willow scrubs. Purple willow scrubs (Rumici crispi-Salicetum purpureae association) evolves on gravel covered surfaces characterized by extremely wet water conditions. Such surfaces were typical on the riparian zone of the islands along the main flow, and upper zones of the side-arm bank on the islands. On the contrary, almond-leaved willow scrub association (Polygono hydropipero-Salicetum triandrae) develops on silty and sandy surfaces, which was typical along side-arms, mainly in their lower riparian zone. As a consequence of closing the side-arm, previously gravel covered surfaces of its riparian zone are covered by smaller sediments, and thus, the purple willow scrubs only appear on the bank of the islands along the main flow. However, many erosion protection structures were built along the riparian zone which block the development of continuous stands, and therefore, the next successional stage (black poplar stands) cannot evolve. Almond-leaved willow becomes rare; its consociation with white willow is more typical, probably beacause of the deepening water-level and drying of bank zone along the side-arm.
\end{abstract}

Keywords: alluvial forest; plant associtation; poplar stand; riparian habitat; water regulation; willow scrub

\section{Introduction}

The Danube is the most international river in the world [1], and Europe's second largest as well. Today many stretches of the whole river are directly influenced by dams. The Hungarian stretch has remained as free flowing, which is a unique value, but during the last centuries many other artificial interventions harmed the river causing significant effects on its islands and their habitats. In Hungary less than 3\% of the former fluvial forests preserved till present [2]; this shows the scale of the harmful interventions and land use changes.

Succession stages of the Danube floodplain in Hungary was first observed by [3] in the continental delta called Szigetköz, followed by [4,5]. The latter one differentiated 15 natural or semi-natural forest association types and their altogether 40 sub-associations. While zonations on the upper Danube stretches were reported by [6] around Wallsee.

The human presence along the Danube and on its islands is almost as old as the age of the islands. In ancient times the human activities and settlements were adapted to the 
natural circumstances. In dry climate periods they moved closer to the river, which provided drinking water, food etc., while in periods with much precipitation they moved far from the flooded area as described by [7].

Smaller dikes already had been built during the Roman age, but adaptation to the natural floods had been more typical for a long time. Since the 18th century the territorial need for agricultural land use started to increase significantly. The built of the flood prevention dike system along the Danube caused a narrower floodplain [8]. The traditional land uses of the natural habitats which remained on the flood protected area were changed onto intensive land use forms (arable lands, tree plantations), the riverside was occupied by settlements and industries which need direct connection to the river. Due to these processes the previously wide ranged floodplain vegetation is concentrated now only on the islands and on the narrow flooded riverbank areas [9].

The distribution of the floodplain habitats decreased significantly, their remnants have been affected by river regulation interventions since the second half of the 19th century. Gravel bars and islands were removed by dredging, and regulation infrastructures were built to lead and keep the water in the navigation route channel part of the main flow. The most usual structures are the groynes, the parallel structures and the rock-fill dams. [10] raised attention onto the connections between hydrological, geomorphological processes and ecological state in case of the formation of floodplain forests.

As a result of the continuously improving navigability, the waterway traffic increased. Besides several other harmful effects, the navigation contributes to the spread of invasive alien species [11], that cause massive degradation of natural habitats.

The establishment of the islands is a result of complex continuous abiotic and biotic processes. The riverbed formation of the Danube is the result of a long term fluvial process, the cumulative effects and the interactions of the natural processes and artificial interventions with the extreme climate conditions are causing so massive negative effects which were never been experienced before, including erosion [12].

The objectives of this study are to gain knowledge about the islands of the Hungarian Danube stretch between Vének and Budapest with priority attention to the landscape history and historical land uses of the islands, as well as to explore the current floodplain forest associations that cover the islands and their potential successional processes.

\section{Methods}

The study area is the islands of the Danube stretch between Vének (1797 riverkilometer $=\mathrm{rkm})$ and Budapest $(1648 \mathrm{rkm})$.

To gain knowledge about the age of the islands' surface we made general and detailed landscape historical investigations.We studied the Hungarian geographical researches and references [13-16] in order to collect the list of potential mappings about the Danube from island point of view. During the searching work of the available maps and surveys we visited the following institutions: Map Archive of the Military History; National Archives of Hungary; Danube Museum; Special Library of Water and Environmental Protection. The online Hungaricana (Hungarian Cultural Heritage Portal), Mapire (Historical Maps Online), Fentrol.hu (Online Aerial Photo Archive) and Google Earth Pro contribute a lot to the remote access to a huge amount of sources. As part of the general landscape historical research we analysed visually 29 mappings from the last 250 years, respectively. We also analysed visually a large amount of aerial photos and satellite images to follow the development of each association and the successional changes of the selected stands since the 1940s.

On the field we prepared 85 coenological samplings on 22 selected islands between 2007 and 2012. We selected both young and old aged islands, there age were determined based on the landscape historical studies.

During the field floristical and vegetation investigations we followed the nomenclature of the latest plant determination book [17], while in case of habitat types we used the General National Habitat Classification System (ÁNÉR) of [18]. In case of the names of 
plant associations we followed the Hungarian Associations Red Book [19]. We used the detailed coenological descriptions of $[20,21]$ and some results from our previous field studies $[22,23]$ in order to interpret the succession processes that are typical in floodplain forests with a view on landscape history relations and historical management forms as well.

\section{Results and Discussion}

The islands are more or less modified with severe disturbance, but they still serve as ecological corridors. Almost every island that are in a close-to-natural state and less disturbed are affected by structures, their side-arm shows different levels of silting-up, which endangers their subsistence in case of remaining without intervention.

Various land uses and their changes have strongly affected the state of the habitats on the islands. Previous non-intensive land uses (i.e., pasture, hayfield, orchard, forest) were changed onto intensive tree plantations after the 2nd World War, especially on those areas that were covered by white poplar stands (Senecioni sarracenici-Populetum albae) and black poplar stands (Carduo crispi-Populetum nigrae) before. Both the foliage level and the grass level of these tree plantations are poor in plant species, and the disturbance during their planting opened floor for invasive alien species, while the species characteristic for valuable marshlands and floodplain forests have totally disappeared. This alteration in species pool is definitely significant in case of those plantations that cover previous marshlands and wet hayfields. Moreover, the cultivars and hybrids used by intensive forest management (Populus $\times$ canescens, $P . \times$ euramericana) may hybridize with native tree species (Populus alba, P. nigra) and this results transitional forms, which endangers the genetic stock of native floodplain forest species.

First pioneer habitats on riparian zones of islands and gravel bars where the surface raises above water level are willow scrubs. Two associations may appear, depending on the ecological factors of the site (i.e., the gravel bar surface), and the sediment that builds up the island's riparian zone. Purple willow scrubs (Rumici crispi-Salicetum purpureae association) evolves on gravel covered surfaces characterized by extreme water regime. Such surfaces were typical on the riparian zone of the islands along the main flow, and upper zones of the side-arm bank on the islands. On the contrary, almond-leaved willow scrub association (Polygono hydropipero-Salicetum triandrae) develops on silty and sandy surfaces, which is typical along side-arms, mainly in their lower riparian zone. As a consequence of closing the side-arm, previously gravel covered surfaces of the riparian zone of the side-arm have been recently covered by smaller sediments of sand or silt, and thus, the Rumici crispi-Salicetum purpureae association only appears on the bank of the islands along the main flow. However, many erosion protection structures were built along the riparian zone which are blocking the development of continuous stands, and therefore, the next successional stage (black poplar stands) cannot evolve. Almond-leaved willow (Salix triandra), the dominant species of almond-leaved willow scrub stands (Polygono hydropipero-Salicetum triandrae) becomes rare as well; its consociation with white willow (Salix alba) are more typical, or the white willow stands (Leucojo aestiviSalicetum albae) grow directly on the bank without any scrub association. A possible reason for this phenomenon might be the deepening water-level and drying of bank zone along the side-arm.

Well-stated poplar groves can hardly be found along this Danube stretch; only small fragments and edges remained. Only one stand of the successional stage leading towards riparian mixed hardwood forests was found, dominated by European white elm (Ulmus laevis). Considering the riparian softwood forests, only willow groves cover a remarkable rate, endangered by the same factors as the other alluvial associations, i.e., lowering water level and invasive alien species (its intensity depends on the distance from the bank, bigger distance leading to lower water and more invasives).

However, if the damages are not irreversible, alluvial associations have a definitely good regenerative potential. They are able to regenerate after stabilizing the ecological 
factors (e.g., water level, hydrodynamics, soil parameters), if there are propagules of the species. Such sources for regeneration might be the floods that transport propagules from the vegetation of the upper river sections, or the seed bank, and less degraded refugees of the tributaries [24]. Moreover, our landscape history studies showed that there are some patches on every island that were not affected by intensive management. Although they were affected by altered ecological factors as well, but their species stock still preserves more species of the once natural habitats than the abandoned crop fields and intensive tree plantations. These patches regularly cover the edges of the islands. Although most of the islands' edge zones might had been severly modified due to natural or artificially altered hydrodynamics during the last centuries, but it is an interesting aspect that the riverbanks (also on the islands) served as routes for those people and livestock that were towing the ships before the steamboats have become prevalent. Due to this reason their vegetation had regularly been cut back since as early as the 13th century. The activities of keeping these edge zones 'clean' were abandoned more than 100 years before the big land use changes in the second half of the 20th century, and the time passed since then was enough for the natural habitats of these edge zones to regenerate. So theorethically some of those edge areas (depending on the stability of the river section) which are in the most close to natural state now had been regularly cleared during centuries.

\section{Conclusions}

Closing of the side-arm had direct effects on the ecological factors of the islands and their side-arms. The evolvement of previously typical associations (e.g., almond-leaved willow scrub, purple willow scrub) is limited, or not as usual as it would have been in their original site, the successional transition has accelerated and changed. The occupation of invasive alien species is strongly related to the water level, so it depends on the distance from the main river and the side-arm.

The artificially induced hydrodynamic processes affected the current state of the river and its patterns. The sustainable management of the Danube should not be implemented without the deep knowledge of these long-term consequences. Investigations about the above mentioned aspects are very useful to lay down the basis of the responsible management measures.

The key for the regeneration and long-term conservation of the floodplain forests is the reduction of the effects of the existing regulation structures as well as to avoid any new harmful intervention, and implement measures against invasive alien species.

Conflicts of Interest: The authors declare no conflict of interest.

\section{References}

1. Sommerwerk, N.; Bloesch, J.; Paunović, M.; Baumgartner, C.; Venohr, M.; Schneider-Jacoby, M.; Hein, T.; Tockner, K. Managing the world's most international river: The Danube River Basin. Mar. Freshw. Res. 2010, 61, 736-748, doi:10.1071/MF09229.

2. Bölöni, J.; Molnár, Z.S.; Biró, M.; Horváth, F. Distribution of the (semi-)natural habitats in Hungary II. Woodlands and shrublands. Acta Bot. Hung. 2008, 50, 107-148.

3. Zólyomi, B. A Szigetköz növénytani kutatásainak eredményei. Bot. Közl. 1937, 34, 169-193.

4. Kárpáti, I. Az ártéri szintek geomorfológiai- és vegetáció-szukcessziójának kapcsolata. In A cönológiai szukcesszió kérdései; Fekete, G., Ed.; Biológiai Tanulmányok: 1985; Volume 12, pp. 73-81.

5. Kevey, B. A Szigetköz erdeinek szukcessziós viszonyai. Kitaibelia 1998, 3, 47-63.

6. Wendelberger-Zelinka, E. Die Vegetation der Donauauen bei Wallsee. Schriftenreihe der OÖ. Landesbaudirektion $1951,11$.

7. Viczián, I.; Balogh, J.; Kis, É.; Szeberényi, J. A Duna holocén hidromorfológiai változásai a Komárom és Paks közötti folyószakasz szigetein feltárt régészeti lelőhelyek alapján. In Proceedings of the Magyar Földrajzi Napok 2016, VIII, Magyar Földrajzi Konferencia, Eger, Hungary; Pajtókné, T.I., Tóth, A., Eds.; Magyar Földrajzi Társaság, Agria Geográfia Alapítvány, Eszterházy Károly Egyetem: Eger, Hungary, 2016; pp. 94-106.

8. Károlyi, Z. A Duna-völgy vizeinek szabályozása. In A magyar vízszabályozás története; Ihrig, D., Ed.; Országos Vízügyi Hivatal: Budapest, Hungary, 1973.

9. Stančiková, A. A Duna szabályozása. Vízügyi Közlemények 2001, 83.

10. Schneider, E. Formation and evolution of natural softwood stands with respect to water dynamics. Examples from the Loire, Rhine, Elbe and Danube Rivers. Kanitzia 2003, 11, 67-84. 
11. Bartha, D. Veszélyeztetett erdőtársulásaink I. -Fűz-nyár (puhafás) ligeterdők. Erdészeti Lapok 1998, 83, 23.

12. Barczi, A.; Centeri, C.S. Az erózió és a defláció tendenciái Magyarországon. In A talajok jelentősége a 21. században; Stefanovits, P., Michéli, E., Eds.; MTA Talajtani és Agrokémiai Kutatóintézet: Budapest, Hungary, 2005; pp. 221-244.

13. Deák, A.A. A Duna fölfedezése; Esztergom, Hungary, 2004.

14. Dóka, K. A karlsruhei térképek vízrajzi tanulságai. Vízügyi Közlemények 1986, 68, 64-77.

15. Fodor, F. A magyarországi Duna térképi helyzetének fejlődése a XV-XIX. sz.-ban. Földméréstani Közlemények 1954, 6, 15-30.

16. Jankó, A. Magyarország katonai felmérései 1763-1950; Budapest, Hungary, 2007.

17. Király, G. (ed.) Új magyar füvészkönyv. Magyarország hajtásos növényei. Határozókulcsok; Aggteleki Nemzeti Park Igazgatóság: Jósvafő, Hungary, 2009.

18. Bölöni, J.; Molnár, Z.S.; Kun, A. Magyarország élóhelyelyei-Vegetációtípusok leírása és határozója (ÁNÉR 2011); MTA Ökológiai és Botanikai Kutatóintézete: Vácrátót, Hungary, 2011.

19. Borhidi, A.; Sánta, A. Vörös könyv Magyarország növénytársulásairól 2; Természetbúvár Alapítvány Kiadó: Budapest, Hungary, 1999; pp. 119-125.

20. Kevey, B. A Szigetköz erdeinek összehasonlító cönológiai vizsgálata. Thesis, Ineditum, MTA kézirattára, Budapest, Hungary, 1993.

21. Kevey, B. Magyarország puhafás ligeterdei. Kitaibelia 2006, 11, 16.

22. Ádám, S.Z.; Penksza, K.; Malatinszky, Á.; Csontos, P. A Koppánymonostori-sziget kialakulása és tájtörténete. Tájökológiai Lapok (J. Landsc. Ecol.) 2009, 7, 349-360.

23. Ádám, S.Z.; Malatinszky, Á. A Szőnyi-szigetcsoport tájtörténete és vegetációja. Természetvédelmi Közlemények 2012, 18 , 15-23.

24. Csontos, P. A természetes magbank kutatásának módszerei; Scientia Kiadó: Budapest, Hungary, 2001. 